\title{
Acceptability of yoghurt with Marolo pulp (Annona crassiflora Mart.) in the traditional and diet/light formulations
}

\author{
Flávia DELLA LUCIA ${ }^{1}$ \\ Eric Batista FERREIRA ${ }^{2}$ \\ Rodrigo Campos dos SANTOS ${ }^{3}$ \\ Marcela Aparecida Miranda MOREIRA ${ }^{4}$ \\ Síntia Carla CORREA ${ }^{5}$ \\ Eduardo Valério de Barros VILAS BOAS ${ }^{6}$
}

\author{
${ }^{1}$ Professora assistente, Faculdade de Nutrição, Universidade Federal de Alfenas (Unifal-MG), Alfenas, \\ MG, Brasil. \\ E-mail: flavia@unifal-mg.edu.br. \\ ${ }^{2}$ Professor adjunto II, ICEx/UNIFAL-MG. E-mail: eric.ferreira@unifal-mg.edu.br. \\ ${ }^{3}$ Graduando em Química/UNIFAL-MG. E-mail: rodrigocampos2005@yahoo.com.br e \\ marcelaapmm@hotmail.com \\ ${ }_{6}^{5}$ Nutricionista pela Unifal-MG. E-mail: sintia_jacui@yahoo.com.br \\ ${ }^{6}$ Professor Associado III, DCA/UFLA. E-mail: evbvboas@dca.ufla.br
}

Recebido em: 20/08/2012 - Aprovado em: 20/12/2012 - Disponibilizado em: 30/12/2012

\begin{abstract}
The aim of this study was to use marolo pulp in the confection of traditional (sucrose) and diet/light (sodium cyclamate/saccharine (2:1)) yoghurts, with variation in the concentrations of the pulp and sweeteners. The ripe fruit was harvested in Machado-MG and handled at UNIFAL-MG. Six testformulations were made, resulting from the factorial combination of 3 levels of natural and artificial sweetener (1.4\% and $1.9 \%$ of sodium cyclamate/saccharine and $14,4 \%$ sucrose) with 2 levels of pulp (20\% and $30 \%)$. The acceptance test was performed using the hedonic scale (9 points) with 30 panelists. Every acceptance grade remained between 6 and 8. The interaction sweetener*pulp was significant, therefore, analised. For the formulations with $20 \%$ pulp, the use of sucrose was more accepted, with average grade 0.68 point higher than the formulations containing artificial sweetener. Among the sweeteners, the dose containing $1.4 \%$ got significantly higher scores than the doses with $1.9 \%$. The formulations with $30 \%$ pulp, didn't present significant difference among the different types of sweeteners. For the use of $1.9 \%$ artificial sweetener the concentration of $30 \%$ pulp was most accepted. In the internal preference mapping, there isn't difference in acceptation of formulations with $1.4 \%$ sodium cyclamate/saccharine with $20 \%$ and $30 \%$ of pulp and sucrose with $20 \%$ and $30 \%$ of pulp. There was superiority in the acceptability of the formulations with sucrose in relation to the artificial sweetener, and also, when comparing the $1.4 \%$ to the $1.9 \%$ artificial sweetener concentrations. It is concluded that yoghurt may be well accepted, mainly when sweetened with sucrose.

keywords: Marolo; yoghurt; acceptability; internal preference mapping.
\end{abstract}

\section{INTRODUCTION}

The Brazilian Savannah is a biome, with an approximate area of 1.8 million $\mathrm{km}^{2}$, that supplies the market with its exotic native fruits, which have attracted attention from all over the world due to their unique flavor and nutritional value (BRANNSTROM et al., 2008). As an example of these fruit crops we may cite the araticum or marolo (Annona crassiflora Mart.), as one among the 25 most frequent species in this biome (SOARES et al., 2009).

Belonging to the Annonaceae family, marolo is an arboreous species that produces fruit whose pulp coloring ranges from white to yellow (SOARES et al., 2009). According 
to Silva Gomes and Martins (2009), the usual yielding of the fruits varies between $55 \%$ and $65 \%$. Marolo pulp presents $106.83 \mathrm{kcal} / 100 \mathrm{~g}$ as energetic value, constituting a good source of vitamin C (44.97 mg/100g). The fruit also contains expressive amounts of total carotenoids $(2.822 \mu \mathrm{g} / 100 \mathrm{~g})$ and tannin $(3.74$ $\mathrm{mg} / 100 \mathrm{~g}$ ), which are important for the sensory characteristics and functional value of the fruit. Besides, it is also a source of carbohydrates $(14.77 \mathrm{~g} / 100 \mathrm{~g})$, and mineral salts such as potassium (288.36 $\mathrm{mg} / 100 \mathrm{~g})$, phosphorus (21.85 mg/100g), magnesium (20.21 mg/100g) and calcium $(10.39 \mathrm{mg} / 100 \mathrm{~g}$ ) (DRAGANO et al., 2010).

Marolo is very appreciated in culinary due to its unique aroma and flavor, being used in juice, ice-cream, jelly, jam and liquor manufacturing (CORRÊA et al., 2011). Another possible alternative, still little exploited, would be the use of marolo pulp in the confection of yoghurt. This would be an innovation, because there is very scarce use the savannah's fruit in yoghurt production (OLIVEIRA et al., 2008). Besides, yoghurt has presented an increase in consumption within the Brazilian population over the last years, about $3 \mathrm{~kg}$ a year per capita. However, this value is still low when compared to countries such as Uruguay and Argentina with $7 \mathrm{~kg} /$ year, or France with 19 kg/year per capita (SANTANA et al., 2006).
Light/diet foods have contributed for the increase in yoghurt consumption. This change in the consumers' behavior is due to a greater concern for the ingestion of healthier products containing high nutritional value. Besides, the dissociation of the name diet/light from health problems or weight loss has contributed for this increase (RIBEIRO et al., 2010).

Understanding this new consumer's profile is very important for the food industry, mainly when there is interest in marketing a new product. In this context, market research techniques are great tools for providing the knowledge about the consumer's needs, their habits, besides evaluating product prototypes (POLIGNANO, 2001). Therefore, the aim of this study was to use marolo pulp in the confection of traditional and diet/light yoghurts, as well as checking their acceptability.

\section{MATERIALS AND METHODS}

The fruits were collected ripe at a rural property in Machado-MG and transported to the laboratory of Dietetic Techniques at the Nutrition Department from the Federal University of Alfenas - UNIFAL-MG, where they were sanitized after reaching the ideal ripening for consumption, then having their 
rind removed manually. The granules that covered the carpels were eliminated with the use of a stainless steel knife, before washing them. The seeds were extracted from the carpels, which were conserved in plastic bags at $-18^{\circ} \mathrm{C}$ until their utilization. Six test formulations were elaborated, resulting from the factorial combination of 3 levels of natural and artificial sweetener $(1.4 \%$ and $1.9 \%$ sodium cyclamate /saccharin, and $14.4 \%$ sucrose) and 2 levels of pulp (20\% and 30\%) (Table 1).

Table 1- Composition of the yoghurt formulations traditional and diet/light with marolo pulp.

\begin{tabular}{cccc}
\hline Formulations & Sucrose $(\%)$ & Sodium Cyclamate/Saccharin $(\%)$ & Pulp $(\%)$ \\
\hline A & - & 1,9 & 20 \\
B & 14,4 & - & 20 \\
C & 14,4 & - & 30 \\
D & - & 1,9 & 30 \\
E & - & 1,4 & 20 \\
F & - & 1,4 & 30 \\
\hline
\end{tabular}

For producing the yoghurt, $1 \mathrm{~L}$ of pasteurized milk type B, purchased at the local market, was heated up to $45-50^{\circ} \mathrm{C} .100 \mathrm{~mL}$ was collected for diluting powdered milk, and then was added to the rest of the milk when this reached approximately $94-95^{\circ} \mathrm{C}(17 \mathrm{~g} / \mathrm{L})$. This mixture was keeping it under gentle heating for 5 minutes, and then immediately cooled down to $42^{\circ} \mathrm{C}$. $1 \mathrm{~g}$ of commercial lyophilized ferment $\left(\mathrm{BIORICH}^{\circledR}\right.$ - Lactobacillus acidophilus, Bifidobacterium and Streptococcus thermophilus) was previously dissolved in 90 $\mathrm{mL}$ of cold milk; this mixture was divided into three equal parts. $30 \mathrm{~mL}$ of previously prepared lactic ferment was added to the mixture at $42^{\circ} \mathrm{C}$, and incubated it in BOD (QUIMIS ${ }^{\circledR}$ Q-
$315 \mathrm{M})$ at $42^{\circ} \mathrm{C}$ for 3 hours and 30 minutes. After this procedure, the yoghurt was chilled in an iced bath for 15 minutes and maintained at $7^{\circ} \mathrm{C}$ for 4 hours.

For the fruit basis preparation, the marolo pulp was heated in $750 \mathrm{~mL}$ of water during 20 minutes for the elimination of residual granules. The remaining water was poured out and the sucrose solution was added and gently heated for 20 minutes, and subsequently mashed in a multiprocessor for 5 minutes. In the diet/light version of the product, the sucrose was replaced by the sodium cyclamate/saccharin sweetener (2:1) (Tal e Qual®) with the concentrations established in a previous study. For the final 
product, the yoghurt was liquefied with the pulp previously prepared, and kept refrigerated at $7^{\circ} \mathrm{C}$.

The proposed sensory analysis was performed by 30 panelists, composed by students and staff of both genders from UNIFAL-MG with ages ranging between 18 and 50. All the panelists were elucidated about the research protocol (Ethics Committee in Research - $\mathrm{n}^{\mathrm{o}}$ 23087.001220/2008-17). The hedonic scale of nine points was used (extremely liked/ extremely disliked) in lab conditions. The samples were served at refrigerated temperature in monadic form, serving about $30 \mathrm{~mL}$ each, in disposable glasses, previously codified with three digits. Two samples per session were presented, totalizing three sessions. The presentation order of the samples was randomized in every session.

The experiment was performed in randomized block design (DBC) and factorial $2 \times 3$. Orthogonal contrasts were made and Tukey's test was carried out at 5\% significance. In addition, the internal preference mapping was done (SCHLICH, 1995).

\section{RESULTS AND DISCUSSION}

All acceptability means were located between 6 (slightly liked) and 8 (liked very much) (Figure 1). The interaction sweetener*pulp was significant in the variance analysis, therefore, unfolded. For the formulations with $20 \%$ pulp, the use of sucrose was more accepted, with average grade 0.68 point higher than the formulations containing artificial sweetener. Among the sweeteners, the dose containing $1.4 \%$ got significantly higher scores than the doses with $1.9 \%$. For the formulations containing $30 \%$ pulp, there was no significant difference between the means of the different kinds of sweeteners. In another unfolding, for the dose containing $1.9 \%$ artificial sweetener, the concentration with $30 \%$ pulp was better accepted. Regarding the other ways of sweetening, both pulp concentrations were statistically equivalent. The highest average grade was for the yoghurt formulation containing $14.4 \%$ sucrose and $20 \%$ pulp, and the lowest grade was for the formulation containing $1.9 \%$ sodium cyclamate/saccharin and $20 \%$ pulp. 


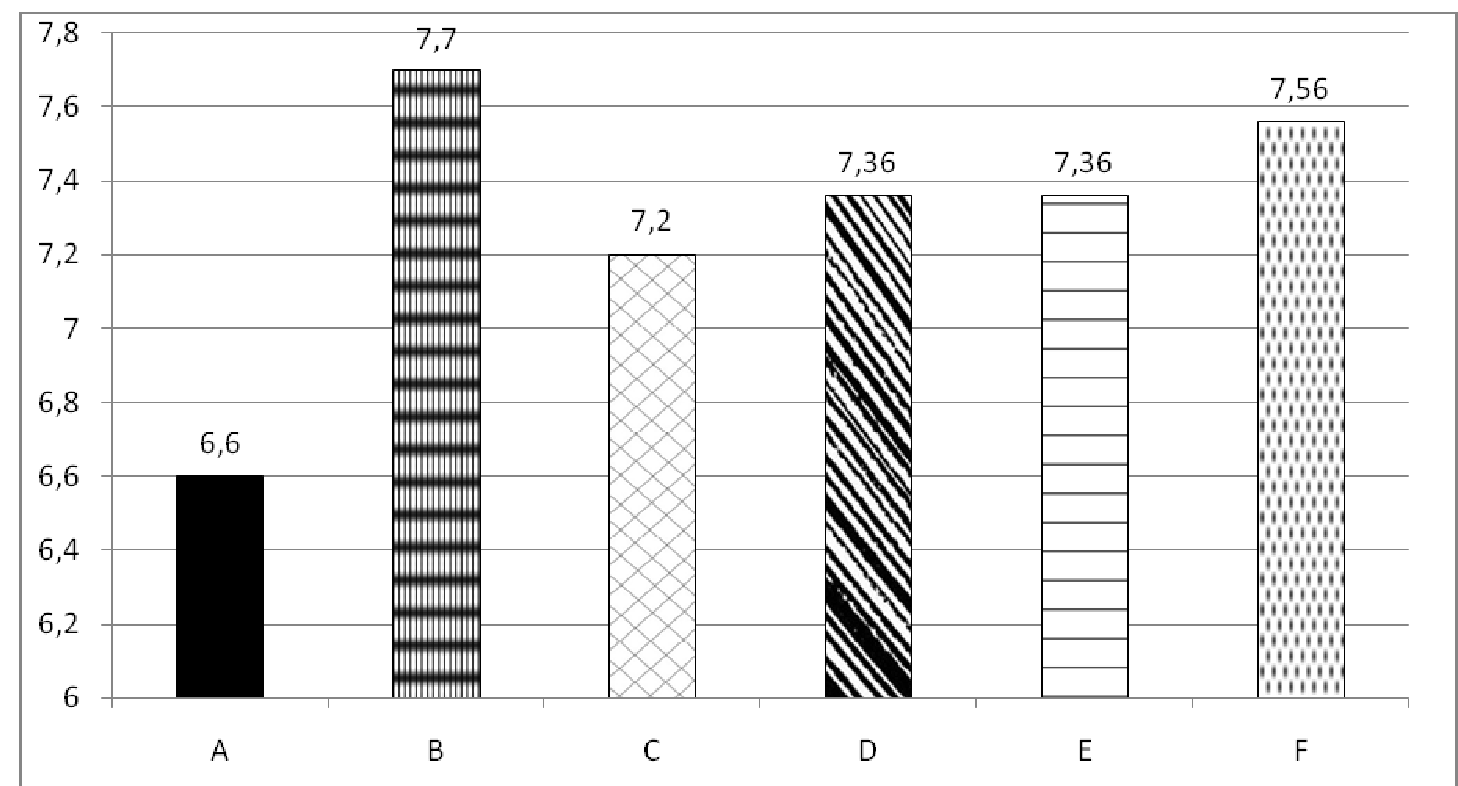

$* \mathrm{~A}-1.9 \%$ sodium cyclamate/saccharin $+20 \%$ pulp; B $-14.4 \%$ sucrose $+20 \%$ pulp; $\mathrm{C}-14.4 \%$ sucrose $+30 \%$ pulp; D $-1.9 \%$ sodium cyclamate/saccharin $+30 \%$ pulp; E $-1.4 \%$ sodium cyclamate/saccharin $+20 \%$ pulp; F $1.4 \%$ sodium cyclamate/saccharin $+30 \%$ pulp.

Figure 1- Acceptability scores of yoghurt formulations with marolo pulp and sweetener*

The results of the internal preference mapping for acceptance are shown in Figure 2. The first main component explains approximately $41.89 \%$ of the total variance, while the second one explains $23.84 \%$, totalizing $65.73 \%$ of variance of the acceptance data. The formulations $\mathrm{E}$ and $\mathrm{F}$ (1.4\% sodium cyclamate/ saccharin with $20 \%$ and $30 \%$ of pulp) form the first group and are considered similar. The formulations B and C
(14.4\% sucrose with $20 \%$ and $30 \%$ pulp) form the second group and formulation $\mathrm{D}$ (1.9\% sodium cyclamate/ saccharin with $30 \%$ pulp) presents an intermediate position. Formulation A (1.9\% sodium cyclamate/ saccharin with $20 \%$ pulp) appears in an opposed position in relation to the rest, therefore different. 

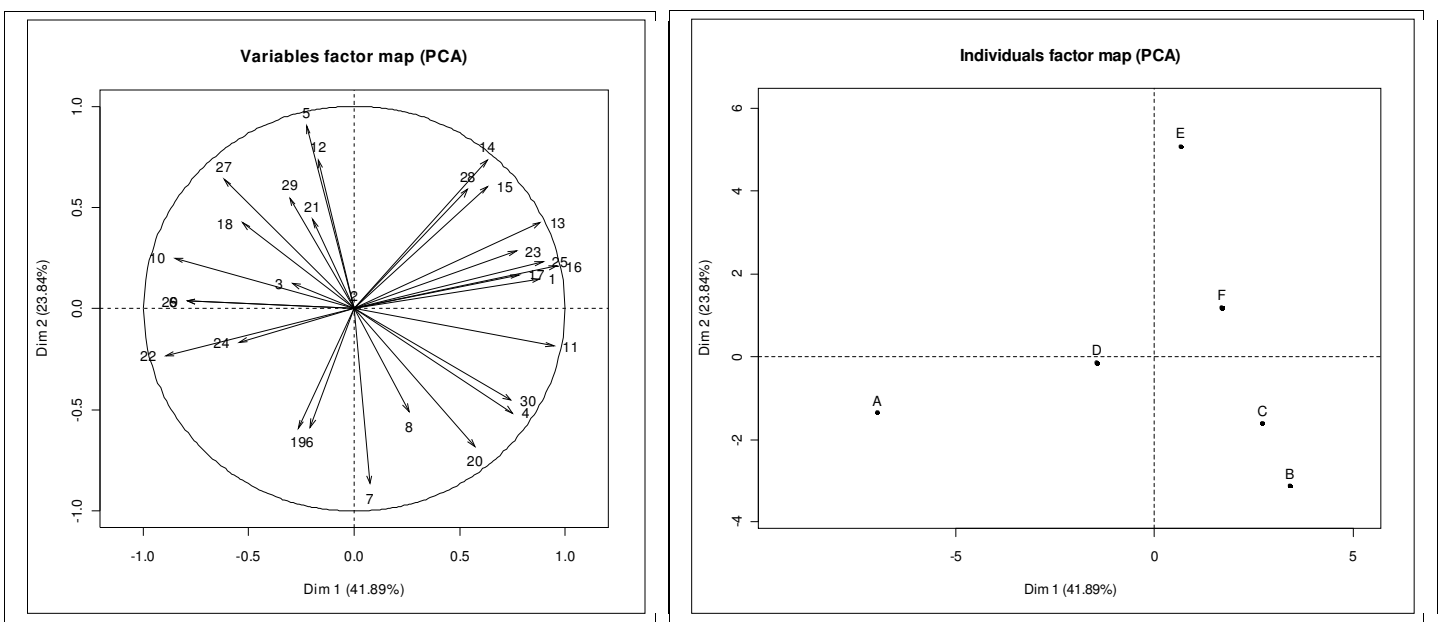

$* \mathrm{~A}-1.9 \%$ sodium cyclamate/saccharin $+20 \%$ pulp; $\mathrm{B}-14.4 \%$ sucrose $+20 \%$ pulp $; \mathrm{C}-14.4 \%$ sucrose $+30 \%$ pulp; D $-1.9 \%$ sodium cyclamate/saccharin $+30 \%$ pulp; E $-1.4 \%$ sodium cyclamate/saccharin $+20 \%$ pulp; F $-1.4 \%$ sodium cyclamate/saccharin $+30 \%$ pulp.

Figure 2 - Internal preference mapping for yoghurt formulations made with marolo pulp and sweeteners*

There was no difference between the formulations containing $1.4 \%$ sodium cyclamate/saccharin with $20-30 \%$ pulp, and those with $14.4 \%$ sucrose with $20 \%$ and $30 \%$ pulp. The formulations $1.9 \%$ sodium cyclamate/saccharin present lower acceptability, mainly in the proportion of $20 \%$ marolo pulp. These results prove what has been observed in the contrast analysis, showing superiority of the formulations with sucrose in comparison to those with artificial sweetener, as well as the $1.4 \%$ in relation to $1.9 \%$ artificial sweetener concentration. Several studies show more acceptability to products elaborated with sucrose compared to those with artificial sweetener, because they are generally prominent in appearance and flavor. Besides the sweet taste, sucrose increases the viscosity, giving suitable texture and stability (ALONSO \& SETSER, 1994).

We have obtained success in replacing the sucrose by sodium cyclamate/saccharin, because there was not loss of flavor and physical characteristics when compared to the product sweetened with sucrose. However, when we increased the artificial sweetener concentration (1.9\%), and adding to that, we decreased the pulp content, there was a decrease in acceptability. The results suggest that a higher concentration of pulp influenced positively the average acceptability, once the strong taste of marolo has probably masked the artificial sweetener residual taste, mainly because saccharin has a 
bitter residual taste. Oliveira et al. (2008), while developing a marolo yoghurt formulation $(0,12.5,25$ and $50 \%$ pulp with $15 \%$ sucrose $)$ verified that in the $12.5 \%$ and $25 \%$ pulp concentrations, the acceptance scores were 7 and 6.2 respectively. Using $50 \%$ concentration, the score decreased (5.6), which proves that the amount of pulp is important for the acceptance of the product, and must contain concentrations below $50 \%$, as those used in the present study.

Upon analyzing the average of the judgments for the different samples (Figure 1), it is possible to infer that all samples, except formulation A, present satisfactory scores. Such fact is important, since it deals with a product with good acceptability with higher aggregated value for attending the soaring request for dietetic products.

There is preference for yoghurt sweetened with sucrose and a low concentration of marolo pulp, however, when sodium cyclamate/saccharin was used, there was preference for the yoghurt containing higher pulp concentration, which highlights the possibility of marolo masking the residual taste of the sweetener. Besides, the acceptability of the product was higher in the samples that contained lower sweetener concentrations independently from the amount of pulp.

\section{CONCLUSION}

According to the results of the sensory evaluation it is possible to infer that all the samples, except the formulation with $1.9 \%$ sodium cyclamate/saccharin and 20\% pulp, constitute good market alternatives. Therefore, we conclude that it is necessary to expand and diversify the elaboration of products containing marolo pulp, suggesting that they will obtain high quality standards and competitiveness in the consumers' market.

\section{REFERENCES}

ALONSO, S.; SETSER, C. Functional replacements for sugars in foods. Trends in Food Science \& Technology, Cambridge, v. 5, n. 5, p. 139-146, 1994.

BRANNSTROM, C.; JEPSON, W.; FILIPPI, A. M.; REDO, D.; XU, Z.; GANESH, S. Land charge in the Brazilian Savanna (Cerrado), 1986-2002: Comparative analysis and implications for land-use policy. Revista Land Use Policy, v. 25, p.579-595, 2008.

CORRÊA, S. C.; CLERICI, M. T. P. S.; GARCIA, J. S.; FERREIRA, E. B.; EBERLIN, M. N.; AZEVEDO, L. Evaluation of dehydrated marolo (Annona crassiflora) flour and carpels by freeze-drying and convective hot-air drying. Food Research International, v.44, p.2385-2390, 2011.

DRAGANO, N. R. V.; VENÂNCIO, V. P.; PAULA, F. B. A.; DELLA LUCIA, F. ; FONSECA, M. J. O.; AZEVEDO, L. 
Influence of Marolo (Annona crassiflora Mart.) pulp intake on the modulation of mutagenic/antimutagenic process and its action on oxidative stress in vivo. Plants Food for Human Nutrition, v. 65, p.319-325, 2010.

OLIVEIRA, A. L.; LOPES, R. B.; CABRAL, F. A.; EBERLIN, M. N. Volatile compounds from pitanga fruit (Eugenia unifora L.).

Revista Food Chemistry, v. 99, p.1-5, 2006.

OLIVEIRA, K. A. M.; RIBEIRO, L. S.;

OLIVEIRA, G. V.; PEREIRA, J. M. A. T. K.; MENDONÇA, R. C. S.; ASSUNPÇÃO, C. F. Desenvolvimento de formulação de iogurte da araticum e estudo da aceitação sensorial.

Revista Alimentos e Nutrição, Araraquara, v.19, n.3, p. 277-281, Jul./Set. 2008.

POLIGNANO, L. A. C.; DRUMOND, F. B. O papel da pesquisa de mercado durante $\mathrm{O}$ desenvolvimento de produtos. In: CONGRESSO BRASILEIRO DE GESTÃO DE DESENVOLVIMENTO DE PRODUTOS, 3, 2001, Florianópolis. Anais... Florianópolis: UFSC, 2001, p.121-130.

RIBEIRO, M. M.; MINIM, V. P. R.; MINIM, L. A.; ARRUDA, A. C.; CERESINO, E. B.; CARNEIRO, H. C. F.; CIPRIANO, P. A.

Estudo de mercado de iogurte da cidade de Belo Horizonte/MG. Revista Ceres, Viçosa, v. 57, n. 2, p.151-156, Mar./Abr. 2010.

SANTANA, L. R. R.; SANTOS, L. C. S.; NATALICIO, M. A.; MONDRAGONBERNAL, O. L.; ELIAS, E. M.; SILVA, C. B.; ZEPKA, L. Q.; MARTINS, I. S. L.; VERNAZA, M. G.; CASTILLO-PIZARRO, C.; BOLINI, H. M. A. Perfil sensorial de iogurte light, sabor pêssego. Revista Ciência e
Tecnologia de Alimentos, Campinas, v.26, $\mathrm{n}$. 3, p.619-625, Jul./Set. 2006.

SCHLICH, P. Preference Mapping: Relating Consumer Preferences to Sensory or Instrumental Measurementes. Dijon, France: Bioflavour 95, v. 75, p. 135-150. 1995.

SILVA, A. M. L.; GOMES, A. C. G.; MARTINS, B. A. Alterações físico-químicas e estudo enzimático da popa de araticum (Annona crassiflora Mart.). Estudos, Goiania, v.36, n.5/6, p. 775-783, Maio/Jun. 2009.

SOARES, F. P.; PAIVA, R.; NOGUEIRA, R. C.; STEIN, V. C.; SANTANA, J. R. F.

Marolo: uma frutífera nativa do Cerrado. Lavras: Universidade Federal de Lavras, Boletim Técnico, n. 82, 2009. 